\title{
Edema induced by Bothrops asper (Squamata: Viperidae) snake venom and its inhibition by Costa Rican plant extracts
}

\author{
Beatriz Badilla ${ }^{1 *}$, Fernando Chaves ${ }^{2}$, Gerardo Mora ${ }^{3} \&$ Luis J. Poveda ${ }^{4}$ \\ Instituto de Investigaciones Farmacéuticas, INIFAR, Facultad de Farmacia, Universidad de Costa Rica. \\ Instituto Clodomiro Picado, Facultad de Microbiología, Universidad de Costa Rica; fchaves@icp.ucr.ac.cr \\ Centro de Investigaciones en Productos Naturales, CIPRONA, Universidad de Costa Rica; gamora@cariari.ucr.ac.cr \\ 4 Escuela de Ciencias Ambientales, Facultad de Ciencias de la Tierra y el Mar, Universidad Nacional, Heredia, Costa Rica; \\ ljpoveda@una.ac.cr \\ * Corrresponding author: Beatriz Badilla INIFAR, Facultad de Farmacia, Universidad de Costa Rica. Fax (506)-225- \\ 35-74; bbadilla@cariari.ucr.ac.cr
}

Received 31-I-2004. Corrected 19-VIII-2004. Accepted 08-VII-2005.

\begin{abstract}
We tested the capacity of leaf(Urera baccifera, Loasa speciosa, Urtica leptuphylla, Chaptalia nutans, and Satureja viminea) and root (Uncaria tomentosa) extracts to inhibit edema induced by Bothrops asper snake venom. Edema-forming activity was studied plethysmographically in the rat hind paw model. Groups of rats were injected intraperitoneally with various doses of each extract and, one hour later, venom was injected subcutaneously in the right hind paw. Edema was assessed at various time intervals. The edematogenic activity was inhibited in those animals that received an injection U. tomentosa, C. nutans or L. speciosa extract. The extract of $U$. baccifera showed a slight inhibition of the venom effect. Extract from $S$. viminea and, to a lesser extent that of $U$. leptuphylla, induced a pro-inflammatory effect, increasing the edema at doses of $250 \mathrm{mg} / \mathrm{kg}$ at one and two hours. Rev. Biol. Trop. 54(2): 245-252. Epub 2006 Jun 01.
\end{abstract}

Key words: anti-edematogenic activity, plant extracts, snake venom, Bothrops asper.

The bites by crotaline snakes induce a prominent local tissue damage characterized by edema, hemorrhage and myonecrosis (Ownby 1982, Gutiérrez and Lomonte 1989, Gutiérrez 2002, Lamar and Sasa 2003, Pinto et al. 2003). Bothrops asper, the specie responsible for most of the snakebites in Central America (Gutiérrez 1995), causes a very important local edema (Chaves et al. 1989). The mouse or rat foot pad assay is the principal model used in order to study antiinflammatory activity. Previous studies dealing with edema induced by $B$. asper venom, using the mouse foot pad assay, showed different results when lower doses $(1 \mu \mathrm{g}$ per mouse) rather than higher doses $(50 \mu \mathrm{g}$ per mouse) of venom were used (Lomonte et al.
1993). Higher doses also induced prominent myonecrosis and hemorrhage (Gutiérrez and Chaves 1980). The edema model, as measured by plethysmographic procedures in rats, is one of the best in vivo models used in order to determine anti-inflammatory activity. Trebien and Calixto (1989) applied this model using rats and concluded that the edema induced by $B$. jararaca venom is mediated by cyclooxygenase and lipoxygenase eicosanoid products and by the activation of $\alpha 1$ and $\alpha 2$ adrenergic receptors. The early edema induced in mice by $B$. asper myotoxin I, a basic phospholipase $A_{2}$, is partially due to histamine and/or serotonin, whereas the last phase of this response is owing to eicosanoids (Gutiérrez et al. 1986, Chaves et al. 1998). 
Inflammatory effects caused by $B$. asper are poorly neutralized by commercial antivenoms used for the treatment of these envenomations (Gutiérrez et al. 1981, Lomonte 1985, Gutiérrez and Lomonte 1989). Thus, there is a need to find new therapeutic alternatives to alleviate inflammation, which is an important feature in these envenomations.

Plants have been used successfully for the treatment of many diseases (Senior 1996, Ahlemeyer and Krieglsteim 2003). Ferreira et al. (1992) have shown, that extracts and fractions obtained from Curcuma longa, used in traditional medicine, have anti-inflammatory, and immuno-modulatory activities. Ethnomedically, many plants have been suggested to have anti-venom activity in several countries. A recent investigation described that at least 578 species of higher plants had some anti-venom action (Martz 1992), so plants constitute an extremely rich source of potential venom-inhibitory substances.

In the present work we investigated the characteristics of the edema induced by $B$. asper venom and the anti-inflammatory activity of the leaves extracts from $U$. baccifera (Urticaceae), L. speciosa (Urticaceae), U. leptuphylla (Urticaceae), C. nutans (Asteraceae), and $S$. viminea (Lamiaceae), and the roots of U. tomentosa (Rubiaceae).

\section{MATERIALS AND METHODS}

Venom. It was obtained from adult specimens of B. asper collected in the Pacific Region of Costa Rica and corresponding to pools from more than 40 individuals. After freeze-drying, the venom was maintained at $-20^{\circ} \mathrm{C}$.

Plant extracts. The plants $U$. baccifera, L. speciosa, U. leptuphylla, C. nutans, S. viminea and $U$. tomentosa were collected during January and March of 1999 in Cartago, Limón and San José (Costa Rica). The plants were identified at source by Luis Poveda and voucher specimens were deposited at the Herbarium of the Universidad Nacional in the following numbers JVR 6997, JVR 7001, JVR 6998, JVR 6995. Specimens of $S$. viminea and $U$. tomentosa were deposited at the Herbarium of the Universidad de Costa Rica with the numbers USJ 0057229 and USJ 63390.

Collected material was washed, chopped and dried for 3 days at about $40^{\circ} \mathrm{C}$, and was ground to a fine dust with a Wiley-type mill. An infusion $(10 \% \mathrm{w} / \mathrm{v})$ was made at $70^{\circ} \mathrm{C}$ for 30 minutes. The solution was filtered out and concentrated using a rotary evaporator at $40^{\circ} \mathrm{C}$. Finally, all plant extracts were freeze-dried and kept at $5^{\circ} \mathrm{C}$ until used.

Experimental animals. Adult male Sprague-Dawley rats (Rattus norvegicus) with a body weight ranging from 180 to $220 \mathrm{~g}$ were used throughout the experiments. These animals were supplied by the Animal Care Unit (Universidad de Costa Rica). The animal protocol was approved by the Committee for the Use and Care of Animals of the University of Costa Rica.

Drugs and chemicals. Indomethacin (Merck), dexamethasone (Merck), diphenhydramine (Merck), sodium chloride (Merck) and sodium bicarbonate (Merck) were used throughout the study.

Evaluation of the of edema induced by $B$. asper. In order to evaluate the edema induced by $B$. asper and establish the challenge-dose, groups of six male rats were injected s.c. in the right hind paw with 100 , $50,25,10$ and $5 \mu \mathrm{g} / 50 \mu \mathrm{l}$ of $B$. asper venom dissolved in $0.15 \mathrm{M} \mathrm{NaCl}$, whereas the left hind paw was injected with $50 \mu \mathrm{l}$ of $0.15 \mathrm{M}$ $\mathrm{NaCl}$. The paw volume was measured plethysmographically (Ugo Basile, model 7140, Italy) at 1, 2, 4, 6 and 24 hours after B. asper venom injection. In addition, groups of six male rats were injected i.p. with various doses of dexamethasone ( 1 and $0.5 \mathrm{mg} / \mathrm{kg}$ ) or with diphenhydramine (50 and $25 \mathrm{mg} / \mathrm{kg}$ ). One hour later, animals were injected s.c. in the right hind paw with $50 \mu \mathrm{g} / 50 \mu \mathrm{l}$ of $B$. asper venom, whereas the left hind paw was injected 
with $50 \mu \mathrm{l}$ of $0.15 \mathrm{M} \mathrm{NaCl}$. The paw volume was measured as described above.

Anti-inflammatory activity. The antiedematogenic properties of the extracts were quantified in the rat paw edema model (Di Rosa et al. 1971). Groups of six male rats were injected i.p. with either 250 or $500 \mathrm{mg} / \mathrm{kg}$ of each extract. One hour later, the animals were injected s.c. in the right hind paw with $50 \mu \mathrm{g} / 50$ $\mu l$ of $B$. asper venom, whereas the left hind paw was injected with $50 \mu \mathrm{l}$ of $0.15 \mathrm{M} \mathrm{NaCl}$. The paw volume was measured at 1, 2, 4, 6 and 24 hours after venom injection. The control group was injected only with venom $(50 \mu \mathrm{g} / 50$ $\mu l)$ in the right hind paw and with saline solution in the left paw. A group of six rats were treated with indomethacin $(100 \mathrm{mg} / \mathrm{kg}$ i.p. $)$ as control for the anti-inflammatory activity. Edema was expressed as percentage of the difference between the left paw and the right paw volumes and compared with venom control.

Statistical analysis. Results are presented as mean \pm S.E.M. $(\mathrm{n}=6)$ and the Student's $t$ test was used to determine the significance of the differences between the mean values of two experimental groups. $p$ values $<0.05$ were considered significant.

\section{RESULTS}

Evaluation of the edema induced by $B$. asper. Animals treated with increasing doses of $B$. asper venom, showed a dose-related effect. Maximum effects were obtained with $100 \mu \mathrm{g} / \mathrm{rat}$. The dose of $50 \mu \mathrm{g}$ was selected as challenge dose for the determination of the anti-inflammatory activity of plant extracts (Fig. 1A). The results obtained with treatment with dexamethasone and diphenhydramine are shown in Fig. 1B and Fig. 1C. Only dexamethasone was able to significantly reduce venominduced edema.

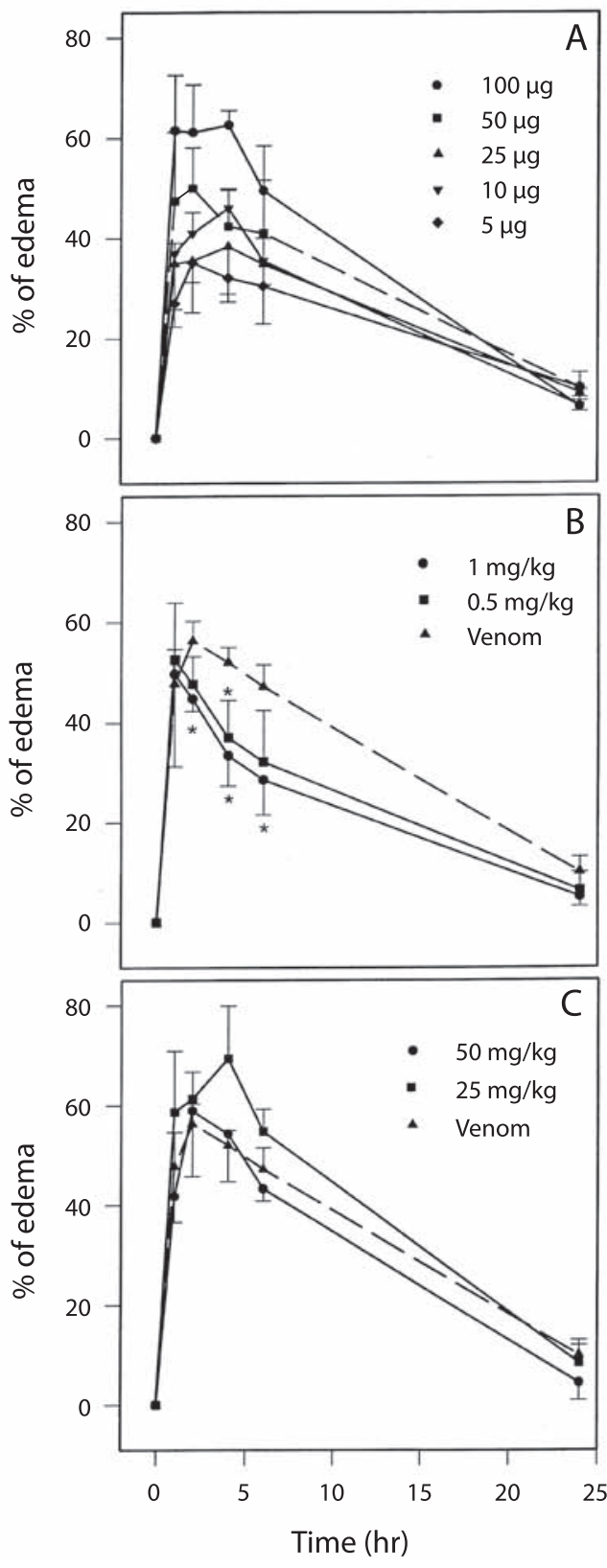

Fig. 1. Bothrops asper edema-forming activity in the rat hind paw model. A. Dose-response curve of $B$. asper venom. B. Inhibition of inflammatory effect of $B$. asper venom $(50 \mu \mathrm{g} / 50 \mu \mathrm{l})$ by dexamethasone. C. Inhibition of inflammatory effect of $B$. asper venom $(50 \mu \mathrm{g} / 50 \mu \mathrm{l})$ by diphenhydramine. 
Anti-inflammatory activity. Pretreatment with the extract of $U$. tomentosa diminished considerably the edema-forming activity of B. asper venom. The doses of $250 \mathrm{mg} / \mathrm{kg}$ and $500 \mathrm{mg} / \mathrm{kg}$ showed an antiinflammatory effect at all times, except for the dose of $250 \mathrm{mg} / \mathrm{kg}$ at one hour (Fig. 2A). The extract of C. nutans showed an important dose-dependent reduction of the edematogenic activity of $B$. asper venom at all times measured. Maximum inhibition was achieved with the highest dose tested $(500 \mathrm{mg} /$ $\mathrm{kg}$ ) (Fig. 2B). Figure $2 \mathrm{C}$ shows the time-course of the edema after pretreatment with the extract of $L$. speciosa. In this case, animals evidenced a sedative effect. Those treated with $500 \mathrm{mg} / \mathrm{kg}$ died after 4 hours, therefore two more groups were treated with 125 and $62.5 \mathrm{mg} / \mathrm{kg}$. The higher inhibitory effect was observed at a dose of $250 \mathrm{mg} / \mathrm{kg}$ (Fig. 2C). Furthermore, a not significant inhibition of edema was observed in animals pretreated with extracts at doses of 125 and $62.5 \mathrm{mg} / \mathrm{kg}$ (Fig. 2C). U. baccifera induced an important reduction of the edema induced by $B$. asper venom at all times measured (Fig. 3A). A partial inhibition was observed in the animals treated with extracts of $U$. leptuphylla and $S$. viminea. Animals pretreated with $U$. leptuphylla $(250 \mathrm{mg} / \mathrm{kg})$ presented a pro-inflammatory effect at 1 and 2 hours. This effect was not observed in animals treated with the dose of $500 \mathrm{mg} / \mathrm{kg}$ (Fig. 3B). In the case of S. viminea, a pro-inflammatory effect was observed at 1,2 and 4 hours with $250 \mathrm{mg} / \mathrm{kg}$. At the other times of measurement the results were similar to those of U. leptuphylla (Fig. 3C). Indomethacin inhibited the edema at all times after venom injection (results not shown).

\section{DISCUSSION}

In this work we demonstrated the characteristics of the edema induced by $B$. asper venom in rats, showing the classical two phases that were described in mice (Chaves et al. 1995). We also demonstrated that extracts

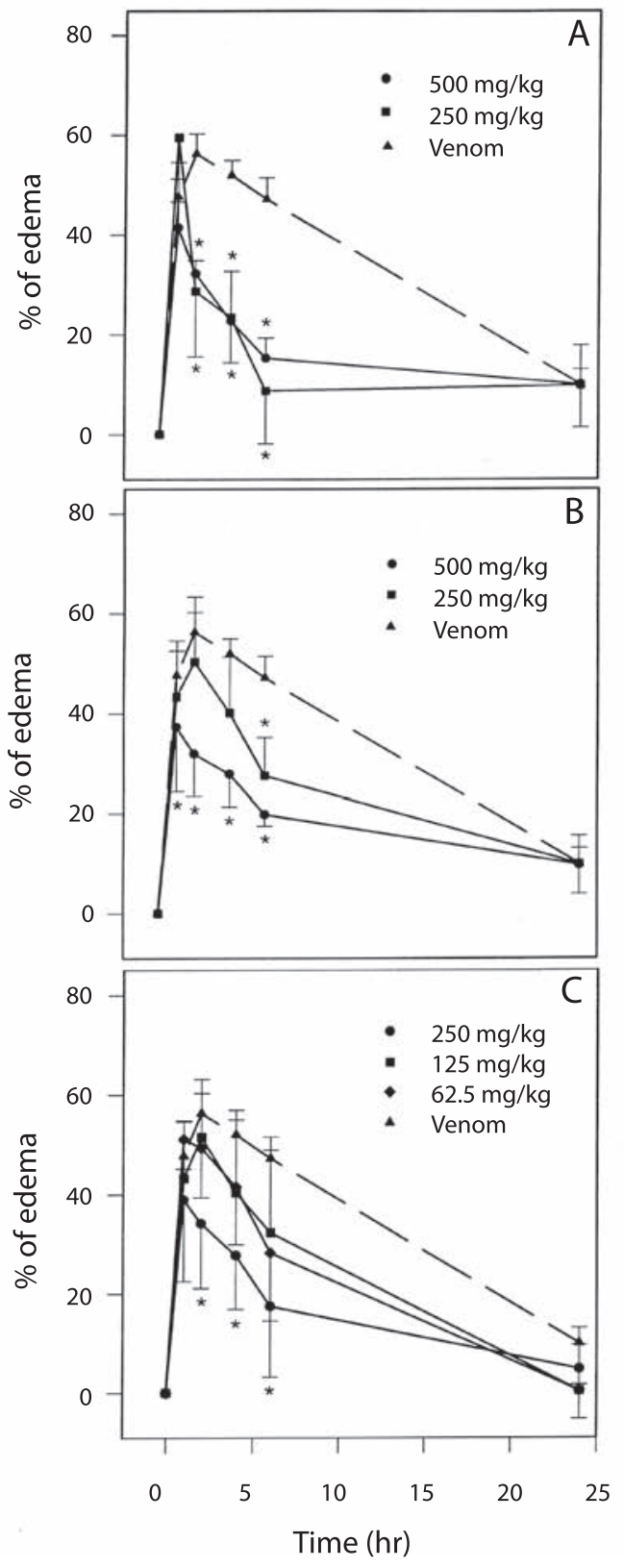

Fig. 2. Anti-inflammatory activity of three plant extracts in the rat hind paw model induced by $B$. asper venom. Groups of rats $(n=6)$ were injected i.p with different doses of U. tomentosa (A), C. nutans (B) and L. speciosa (C). Indomethacin $(100 \mathrm{mg} / \mathrm{kg})$ was used as anti-inflammatory drug in all experiments. Results are shown as mean $\pm \mathrm{SD}$ $(* \mathrm{p}<0.05)$. 


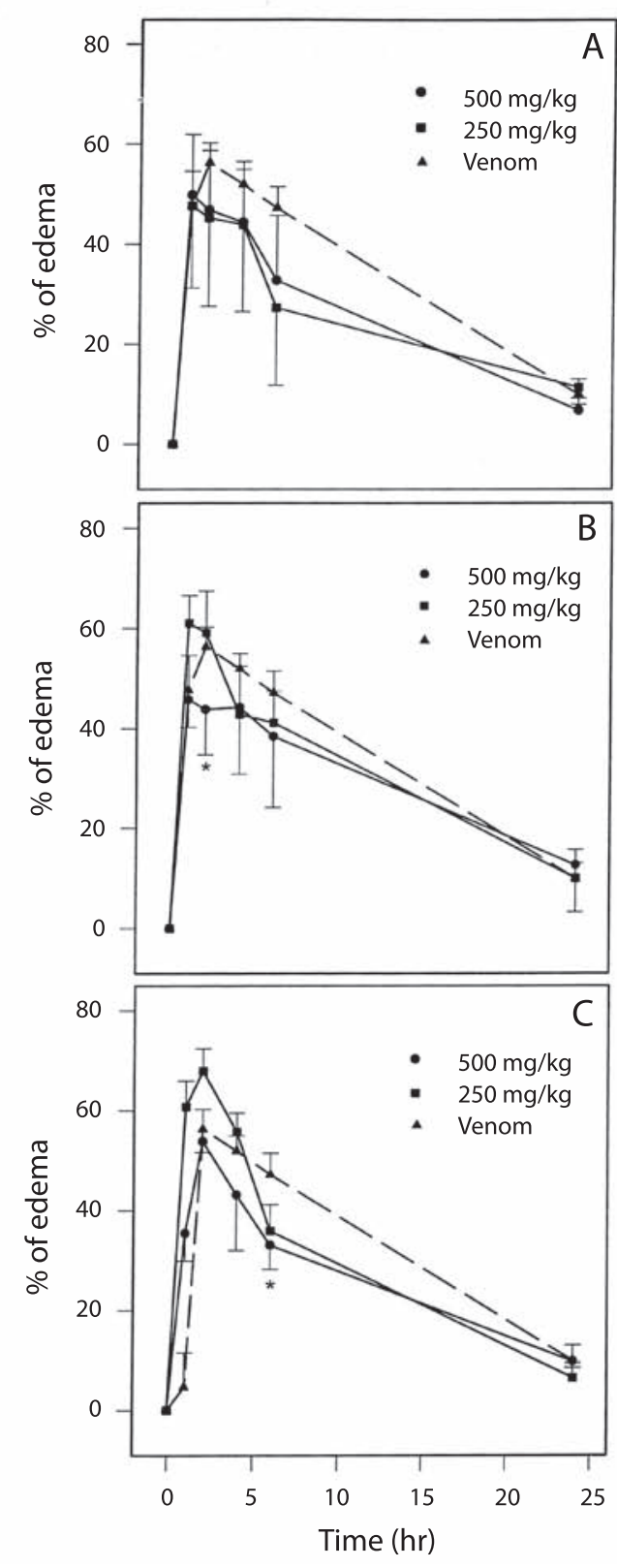

Fig. 3. Anti-inflammatory activity of three plant extracts in the rat hind paw model induced by $B$. asper venom. Groups of rats $(n=6)$ were injected i.p with different doses of U. baccifera (A), U. leptuphylla (B) and S. viminea (C). Indomethacin $(100 \mathrm{mg} / \mathrm{kg})$ was used as anti-inflammatory drug in all experiments. Results are shown as mean $\pm \mathrm{SD}$ $(* \mathrm{p}<0.05)$. of $U$. tomentosa, C. nutans and L. speciosa were able to neutralize the edema induced by $B$. asper venom. These two last species have been previously found to have anti-inflammatory activity in the carrageenan induced model (Badilla et al. 1999a).

One of the consequences of snakebites is local inflammation, especially in the crotaline species (Rosenfeld 1971, Ownby 1982, Gutiérrez et al. 1986; Chaves et al. 1995). B. asper, the most important snake in Central America (Campbell and Lamar 1989, Hardy 1994), induces a striking immediate dosedependent edema in mice (Lomonte et al. 1993, Chaves et al. 1995). This snakebite may lead to shock, because of the loss of fluid, and to tissue compression (Garfín et al. 1985) which would contribute to the development of cardiovascular disturbances (Carlson et al. 1975). There are many inflammatory mediators which participate in the production of edema in a variety of inflammatory conditions (Posadas et al. 2000). Among others, histamine, prostaglandins, kinins and leukotrienes, could be implicated in the resulting edema in the case of snake venoms (Trebien and Calixto 1989, Chaves et al. 1995).

Edema induced by $B$. asper venom in rats follows the same pattern to the one induced in mice, characterized by a rapid initial first phase produced by mediators such as histamine and serotonin, and a delayed second phase mediated by prostaglandins (Chaves et al. 1995). On the basis of dose- response experiments, a dose of $50 \mu \mathrm{g} / \mathrm{rat}$ was chosen as the challenge-dose, due to its effective inflammatory result without damaging the animal's overall physical integrity, and allowing to show the inhibitory effect of the plant extracts.

Edema seems to be clearly related with prostaglandin production, because an important reduction of the inflammatory effect is induced by dexamethasone, which is a $\mathrm{PLA}_{2}$ inhibitor and by indomethacin a known inhibitor of cyclooxygenase. No histamine effect was shown in this animal model, because the 
doses of diphenhydramine used (50 and 25 $\mathrm{mg} / \mathrm{kg}$ ), were not able to inhibit the first phase of the model.

$U$. tomentosa, C. nutans and L. speciosa extracts significantly reduced venom- induced edema. Since inhibition was observed from 1 to 6 hours, it is likely that the compounds in these extracts are acting both the first and second phases of this inflammatory response (Gutiérrez et al. 1986, Trebien and Calixto 1989, Chaves et al. 1995, Badilla et al. 1999b, Posadas et al 2000). U. tomentosa has already been reported as a plant that inhibits the carrageenan-induced edema (Kiuchi et al. 1983, Aquino et al. 1991, Aguilar et al. 2002); our studies confirm its effect with $B$. asper venom as inflammation inductor.

The effects found in the first 2 hours with $250 \mathrm{mg} / \mathrm{kg}$ of $S$. viminea extracts could suggest an effect on serotonine and histamine liberation, although the effects at 4 to 6 hours suggest an action on prostaglandin production. These effects were not observed at $500 \mathrm{mg} / \mathrm{kg}$. The $U$. leptuphylla had a similar behavior.

Although this study was not designed to investigate the mechanism of inhibition, it might be said that aqueous extracts from $U$. tomentosa, C. nutans and L. speciosa are capable of inhibiting the production of mediators involved in the inflammation process induced by $B$. asper venom, effects that had been found in studies made with plant extracts (Kiuchi et al. 1983).

Currently, the mainstream scientific treatment for snakebite envenomations is the parenteral administration of antivenoms (Warrell 1992). Polyvalent (Crotalinae) antivenom is highly effective in the neutralization of the systemic effects in the case of $B$. asper bites, while local injurious effects are neutralized only to a partial extent (Gutiérrez et al. 1981, 1985). This is attributed to the quick development of local hemorrhage, edema and myonecrosis after venom injection (Gutiérrez et al. 1981, Moreira et al. 1992; Lomonte et al. 1994, Chaves et al. 1995). Therefore, it is necessary to find out complementary treatments aimed at the inhibition of toxins responsible of local tissue damage. Plant extracts constitute a rich source of novel compounds of potential therapeutic interest in the inhibition of venom toxins. In this regard, previous studies performed with crude extracts and fractions of various plants have shown that they posses anti-snake venom activity (Martz 1992). Recently, Borges et al. (2000) demonstrated the ability of extract from Cassearia sylvestris to inhibit phospholipase $\mathrm{A}_{2}$, myotoxic, anticoagulant, and edema-forming activities of some snake and bee venoms and of various phospholipases $\mathrm{A}_{2}$ isolated from these venoms. Our results suggest that the plant extracts investigated contain anti-inflammatory agents that reduce the extent of $B$. asper venom-induced edema.

\section{ACKNOWLEDGMENTS}

The authors thank Lorena Chavarría, Alexis Torres, members of the staff of the Department of Pharmacology and Toxicology, School of Pharmacy, Universidad de Costa Rica and Juan Carlos Brenes, of CIPRONA, for their technical assistance. This work was supported by CONICIT, Ministerio de Ciencia y Tecnología, Costa Rica and Vicerrectoría de Investigación (No 817-98-514), Universidad de Costa Rica. We also thank Norman Farnsworth and NAPRALERT, of the University of Illinois in Chicago, for kindly allowing our access to the database.

\section{RESUMEN}

Se investigó la capacidad de los extractos de las hojas de Urera baccifera, Loasa speciosa, Urtica leptuphylla, Chaptalia nutans, Satureja viminea y de la raíz de Uncaria tomentosa para inhibir el edema inducido por el veneno de Bothrops asper por métodos pletismométricos. Los grupos de ratas fueron inyectados intraperitonealmente con varias dosis de cada extracto y una hora mas tarde se inyectó veneno por vía subcutánea en la pata trasera derecha de la rata. Se evaluó el edema en distintos intervalos de tiempo. Los resultados muestran que la actividad edematogénica fue inhibida en los animales que recibieron los extractos de raíz de $U$. tomentosa, hojas de C. nutans y L. speciosa. Los extractos de hojas de $U$. baccifera mostraron leve 
inhibición del efecto del veneno. El extracto de hojas de $S$. viminea y en menor grado el de $U$. leptuphylla indujeron un efecto pro inflamatorio.

Palabras clave: actividad anti-edematogénica, extractos de plantas, venenos, serpientes, Bothrops asper.

\section{REFERENCES}

Aguilar, J.L., P. Rojas, A. Marcelo, A. Plaza, R. Bauer, E. Reininger, C.A. Klaas \& I. Merfort. 2002. Antiinflammatory activity of two different extracts of Uncaria tomentosa (Rubiaceae) J. Ethnophar. 81: 271-276

Ahlemeyer, B. \& J. Krieglstein. 2003. Pharmacological studies supporting the therapeutic use of Gingo biloba extract for Alzheimer's disease. Pharmacopsychiatry 36: S8-14.

Aquino, R., V. De Feo, F. De Simone, C. Pizza \& G. Cirino. 1991. Plant metabolites and antiinflammatory activity of Uncaria tomentosa. J. Nat. Prod. 54: 453-459.

Atkinson,T. \& M. Witte. 1992. Histamine and serotonins, p. 193-209. In Inflammation: Basic Principles and Clinical Correlates, Raven, New York.

Badilla, B., G. Mora \& L.J. Poveda. 1999a. Anti-inflammatory activity of aqueous extracts of five Costa Rican medicinal plants in Sprague-Dawley rats. Rev. Biol. Trop. 47: 723-727.

Badilla B., G. Mora, A.J. Lapa. \& J.A. Silva-Emmin. 1999b. Anti-inflammatory activity of Urera baccifera (Urticaceae) in Sprague-Dawley rats. Rev. Biol. Trop. 47: $365-371$.

Borges, M., A. Soares \& V. Rodrigues. 2000. Effects of aqueous extract on Cassearia sylvestris (Flacoutiaceae) on actions of snake and bee venoms and on activity of phospholipases $\mathrm{A}_{2}$. Comp. Biochem Physiol. 127: 21-30.

Campbell, J.A. \& W.W. Lamar. 1989. The venomous reptiles of Latin America. Cornell Univ., Ithaca, New York, $425 \mathrm{p}$.

Carlsson, R.W., R.C. Shaeffer, H. Whigham, S. Michaelis, F.R. Russell \& M.H. Weil. 1975. Rattlesnake venom shock in the rat: development of a method. Am. J. Physiol. 229: 1668-1674.

Chaves, F., J.M. Gutiérrez, B. Lomonte \& L. Cerdas. 1989. Histopathological and biochemical alterations induced by intramuscular injection of Bothrops asper (Terciopelo) venom in mice. Toxicon 27: 1085-1093.
Chaves, F., M. Barboza \& J.M. Gutiérrez. 1995. Pharmacological study of edema induced by venom of snake Bothrops asper (Terciopelo) in mice. Toxicon 33: 31-39.

Chaves, F., G. León, V.H. Alvarado \& J.M. Gutiérrez. 1998. Pharmacological modulation of edema induced by Lys-49 and Asp-49 myotoxic phospholipases A2 isolated from the venom of the snake Bothrops asper (Terciopelo). Toxicon 36: 1861-1869.

Di Rosa M., P.J. Giroud \& B.A. Willoughby. 1971. Studies of the mediators of the acute inflammatory response induced in rats in differents sites by carrageenan and turpine. J. Pathol. 101: 15-29.

Ferreira, L., O. Henriques, A. Andreoni, G. Vital, M. Campos, G. Habermehls \& V. Moraes. 1992. Antivenom and biological effects of ar-turmerone isolated from Curcuma longa (Zingiberaceae). Toxicon 30: $1211-1218$

Garfín, S.R., R.R. Castilonia, S.J. Mubarak, A.R. Hargens, W.H. Akeson \& F.E. Russell. 1985. The effect of antivenon on intramuscular pressure elevations induced by rattlesnake venom. Toxicon 23: 677-680.

Gutiérrez, J.M. \& F. Chaves. 1980. Efecto proteolítico, hemorrágico y mionecrótico de los venenos de serpientes costarricenses del género Bothrops. Toxicon 18: 603-610.

Gutiérrez, J.M., F. Chaves, R. Bolaños, L. Cerdas, G. Rojas, O. Arroyo \& E. Portilla. 1981. Neutralization of the local effects of venom Bothrops asper by polyvalent antivenom. Toxicon 19: 493-500.

Gutiérrez, J.M., J.A. Gené \& G. Rojas. 1985. Neutalization of proteolytic and hemorrhagic activities of Costa Rica snake venoms by polyvalent antivenom. Toxicon 23: 887-893.

Gutiérrez J.M., F. Chaves \& L. Cerdas. 1986. Inflammatory infiltrate in skeletal muscle injected with Bothrops asper venom. Rev. Biol. Trop. 34: 209-219.

Gutiérrez, J. M. \& B. Lomonte. 1989. Local tissue damage induced by Bothrops asper snake venom. A review. Mem. Inst. Butantan 51: 211-223.

Gutiérrez, J.M. 1995. Clinical toxicology of snake bite in Central America, p. 645-665. In J. Meir (ed.). Handbook of Clinical Toxicology of Animal Venoms and Poisons. CRC, Boca Raton, Florida.

Gutierrez, J.M. 2002. Comprendiendo los venenos de serpientes: 50 años de investigaciones en America Latina. Rev. Biol. Trop. 50: 377-394. 
Hardy, D.L. 1994. Bothrops asper (Viperidae) snakebite and field researches in Middle America. Biotropica 26: 198-207.

Kiuchi, F., M. Shibuya, T. Kinoshita \& U. Samkawa. 1983. Inhibition of prostaglandin biosynthesis by the constituents of Medicinal Plants. Chem. Pharm. Bull. 31: 3391-3396.

Lamar, W.W. \& M. Sasa. 2003. A new species of hognose pitviper, genus Porthidium, from the southwestern Pacific of Costa Rica (Serpentes: Viperidae). Rev. Biol. Trop. 51: 797-804.

Lomonte, B. 1985. Edema-forming activity of bushmaster (Lachesis muta stenophrys) and Central American rattlesnake (Crotalus durissus durissus) venoms and neutralization by a polyvalent antivenom. Toxicon 23: $173-176$.

Lomonte, B., A. Tarkowski \& L.A. Hanson. 1993. Host response to Bothrops asper snake venom: analysis of edema formation, inflammatory cells and cytokine release in a mouse model. Inflammation 17: 93-105.

Lomonte, B., J. Lundgren, B. Johanson \& U. Bagge. 1994. The dynamics of local tissue damage induced by Bothrops asper snake venom and myotoxin II on the mouse cremaster muscle: an intravital and electron microscopic study. Toxicon 32: 41-55.

Martz, W. 1992. Plants with a reputation against snakebite. Toxicon 30: 1131-1142.

Moreira, L., J.M. Gutiérrez, G. Borkow \& M. Ovadia 1992. Ultrastructural alterations in mouse capillary blood vessels after experimental injection of venom from the snake Bothrops asper (terciopelo). Exp. Mol. Pathol. 57: 124-133.
Moore, B.D., E. Isidoro \& J.R. Seemann. 1993. Distribution of 2-carboxyarabinitol among plants. Phytochemistry 34: 703-707.

Ownby, C.L. 1982. Pathology of rattlesnake envenomation, p. 163-209. In Rattlesnake Venoms. Their actions and treatment. New York.

Pinto, A., Y. Angulo, R. Jiménez \& B. Lomonte. 2003. Isolation of bothrasperin, a disintegrin with potent platelet aggregation inhibitory activity, from the venom of the snake Bothrops asper. Rev. Biol. Trop. 51: 253-260.

Posadas, I., M.C. Terencio, I. Guillén, M.L. Ferrandiz, J. Coloma. M. Payá \& M.J. Alcaraz. 2000. Co- regulation between cyclo-oxygenase- 2 and inducible nitric oxide synthase expression in the time-course of murine inflammation. Arch. Pharmacol. 361: 98-106.

Rosenfeld, G. 1971. Symptomatology, pathology and treatment of snake bites in South America, p. 345-384. In Venomous animals and their venoms. Academic, New York.

Senior, K. 1996. Pharmaceuticals from plants: promise and progress. Mol. Medic. Today 2: 60-64.

Trebien, H.A. \& J.B. Calixto. 1989. Pharmacological evaluation of rat paw edema induced by Bothrops jararaca venom. Agents and Actions 26: 292-300.

Warrell, D.A. 1992. The global problem of snake bite: its prevention and treatment, p. 121-153. In P. Gopalakrishnakone \& C.R. Tan (eds.). Recent advances in Toxicology Research, 1. National University of Singapore, Singapore. 